九州大学学術情報リポジトリ

Kyushu University Institutional Repository

Studies on the growth behaviour and quality of the forage crops in warm area in Japan : IV. Effect of temperature on the growth behaviour and chemical composition of corn, oats and red clover

Ehara, Kaoru

Plant Breeding Laboratory, Department of Agriculture, Kyusyu University

https://doi.org/10.5109/22679

出版情報: 九州大学大学院農学研究院紀要. 11 (2), pp. 109-128, 1959-08. Kyushu University バージョン：

権利関係 : 
Journal of the Faculty of Agriculture, Kyūshū University, Vol. 11, No. 2 August 31, 1959

Studies on the growth behaviour and quality of the forage crops in warm area in Japan

IV. Effect of temperature on the growth behaviour and chemical composition of corn, oats and red clover

\section{KAORU EHARA}

\section{INTRODUCTION}

In Japan and foreign countries, there is a common belief that the forage crops grown under warm climate are inferior in quality than those grown under cold climate. However, there has not been any reliable research made on this subject in Japan, and a few conducted in foreign countries.

The author tried to investigate whether or not the above belief can be substantiated, and if so, to find the cause for, and counter-measure against it.

The geographical region to which each forage crop is adapted is limited by various climatic factors of which temperature is of major importance.

The effects of temperature on growth and chemical composition constitute one of the major problems in the management and utilization of forage crops. Therefore, an advanced knowledge of the temperature relations to forage crops should contribute to the solution of some of the problems of quality improvement of forage crops in warm area.

The species of forage crops included in investigations herein reported are corn (Zea mays), oats (Avena sativa), and red clover (Trifolium pratense).

\section{LITERATURE REVIEW}

Many investigations have been done with forage crops on the effect of temperature on the growth, while there are a few studies on the 
effect of temperature on the chemical, physical or anatomical properties of forage crops.

Walster (1920) who grew barley at two temperatures, found the lower temperature to induce a more upright character of growth because of a greater proportion of culm to leaf, a greater proportion of skeletal material in the leaf to all other plant substances, and a greater degrec of lignification of conductive tissue than was found in plants grown under higher temperatures.

Newton (1922) found that he could distinguish cold-hardy from non-cold hardy varieties of wheat on the basis of their bound water content. He also observed the higher sugar content of the hardy variety as compared with that of the non-hardy, but assigned no particular significance to it. On the other hand, Meyer (1928) stressed the idea that soluble carbohydrates may increase frost resistance of plants by decreasing the precinitation of protein.

Hurd-Karrer and Dickson (1934), Lundegardh (1954), Nightingale (1934, 1935) and Tottingham (1923) all reported that plants accumulate less carbohydrates as the temperature becomes higher.

Delwiche and Totingham (1930) measured the amount of crude protein in clover hay, corn, and barley grain in northern and southern Wisconsin. There were differences in latitude, altitude, length of season, number of fine days, amount of rainfall, and atmospheric moisture in those two places According to them, the accepted opinion that northern crops are richer in protein than southern crops and therefore have higher feeding value was hardly substantiated. On the contrary, clover from northern Wisconsin had less protein than that from southern Wisconsin. Vinall and Hein (1937) showed that the southern limit of the region to which Kentucky and Canada bluegrass and orchard grass are adapted corresponds rather closely with the $60^{\circ} \mathrm{F}$. isotherm. The northern limit for orchard grass corresponds roughly with the $45^{\circ} \mathrm{F}$. isotherm, but the two bluegrasses are successfully grown much farther north.

According to Brown (1937), in Kentucky and Canada bluegrass and orchard grass, the percentage content of nitrogen-free extract declined with rising temperature but in Bermuda grass, this constituent increased in concentration as the temperature rose. In all four grasses, the crude fiber content increased in percentage as the temperature rose from $40^{\circ}$ to $60^{\circ} \mathrm{F}$. and changed little with further rises in temperature. The percentage of crude protein declined slightly in Kentucky and Canada bluegrass and orchard grass as the temperature increased from $40^{\circ}$ to $60^{\circ} \mathrm{F}$. and then increased slightly as the temperature rose above the optimum for growth. In Bermuda grass the crude protein content was much greater at $50^{\circ}$ than $60^{\circ} \mathrm{F}$.

Sullivan and Sprague (1949) found that protein metabolism was 
characterized by an increase in the proportion of soluble nitrogen immediately after the leaves were clipped, and at the highest temperature this proportion continued to increase for a long period in the tops and stubble of perennial ryegrass. Other constituents, lignin, hemicellulose, and ash were not particularly affected by leaf removal or temperature except that their percentage were increased where soluble carbohydrates had been withdrawn. The losses were most rapid and extensive at the higher temperatures. The roots and stubble underwent rapid losses in sucrose and fructosan during the early part of experiment but these losses were partly replaced later under the low temperature conditions. Under the highest temperature these losses were not replaced but continued, especially in the roots, almost to the point of exhaustion and in some cases to the death of the roots. Carrol (1943) also stated that the detrimental effects of high temperatures are the result of a depletion of carbohydrates within the plant.

A review by Weinmann (1948) covers the general subject of reserves in grasses.

Ulrich (1955) found that the sugar beet were grown with an ample supply of water and nutrients in a controlled temperature greenhouse (days $23^{\circ} \mathrm{C}$, nights $17^{\circ} \mathrm{C}$.), and ripenning or "sugaring up" was induced by low night temperatures and nitrogen deficiency, i. e., changes in the external environment rather than by some internal self regulatory mechanism of the plant.

\section{EXPERIMENTAI. METHODS}

In this experiment, thermo-regulated growth chamber was not used. The equipment used for the control of temperature consists of two glasshouses, the windows of the one were opened and those of the other one were closed. The air temperature in the former was lower than the latter, and the former is called the low temperature plot and the latter is called the high temperature plot in this experiment.

The red clover and oats cultures were grown in earthen flower plots, $30 \mathrm{~cm}$. in diameter at the top, $25 \mathrm{~cm}$. in diameter at the bottom, and $30 \mathrm{~cm}$. deep. The corn cultures were grown in glaged earthenware pots, $25 \mathrm{~cm}$. in diameter at the top and the bottom, and $31 \mathrm{~cm}$. deep. The varieties used for this experiment were Northwestern dent corn, Carter's black tartar oats and Dollard red clover.

Corn, oats and red clover were planted directly in the potted soil, and the stands reduced to 2,5 and 3 plants per pot as soon as the seedling appeared to be securely established in corn, oats and red clover respectively. Red clover was sown on December 20, 1955, corn and oats were sown on April 15, and 18, 1956 respectively. Ten cultures of 
each species were established, and 5 cultures of each species were exposured to each different temperature plot from April 24 to June 30, 1956.

Corn plants were cut at silk stage, oats plants were cut at head stage and red clover plants were cut at bloom stage at the soil surface. Fresh and air dry weights are reported as g./pot. During growth period, the measurements of growth were made by each species. Stage of growth of corn and oats plants was indicated by the order of leaf instead of the number of days after sowing. Symbols of the emerging stage of leaf on main stem were the same as those in the previous report (Ehara et al. 1956).

With cut samples gencral chemical analyses were made and sugar and lignin content also was determined. In analysing lignin, colloid titration method as reported by Senju et al. (1955) was employed. The cut samples of corn were separated into leaves, stalks, ears and tassels, and leaves were separated into each leaf by the order of leaf. Oats were separated into leaves of main culn, main culns, heads of main culm and tillers, red clover samples were separated into leaves, stems and thower head. Analytical determinations were made on each organ from the three plants.

\section{RESULTS}

\section{RESULTS OF MEASURING TEMPERATURE IN THE TWO GLASSHOUSES}

The maximum and minimum temperatures and the temperatures at 9 a. m., and at 6 p. m. were measured in the giasshouses. As shown in Figures 1 and 2, in general the temperatures rose with advancing season, and this trend"was most remarkable in the minimum temperatures. The maximum temperatures in the high temperature piot were about $1.3^{\circ}$ to $5.0^{\circ} \mathrm{C}$. higher than those in the low temperature one. The minimum temperatures in the high temperature plot were $1.0^{\circ}$ to $2.5^{\circ} \mathrm{C}$. higher than those in the low temperature plot up to last of June. The maximum and minimum temperatures in the two plots were higher than those in the field conditions, and those differences in temperatures between the glasshouses and field conditions were more remarkable in the maximum temperatures than in the minimum temperatures.

The curves in Figure 2 show that air temperatures at $9 \mathrm{a} . \mathrm{m}$. are $1.8^{\circ}$ to $4.0^{\circ} \mathrm{C}$. higher in the high temperature plot than in the low temperature one throughout experimental period. The air temperatures at $6 \mathrm{p} . \mathrm{m}$. are $0.6^{\circ}$ to $4.0^{\circ} \mathrm{C}$. higher in the former than in the latter.

As above mentioned, a relatively warm condition and a relatively cool condition were obtained by these temperature treatments, but the true temperatures in the two plots were extraordinarily higher than those in the field conditions. 


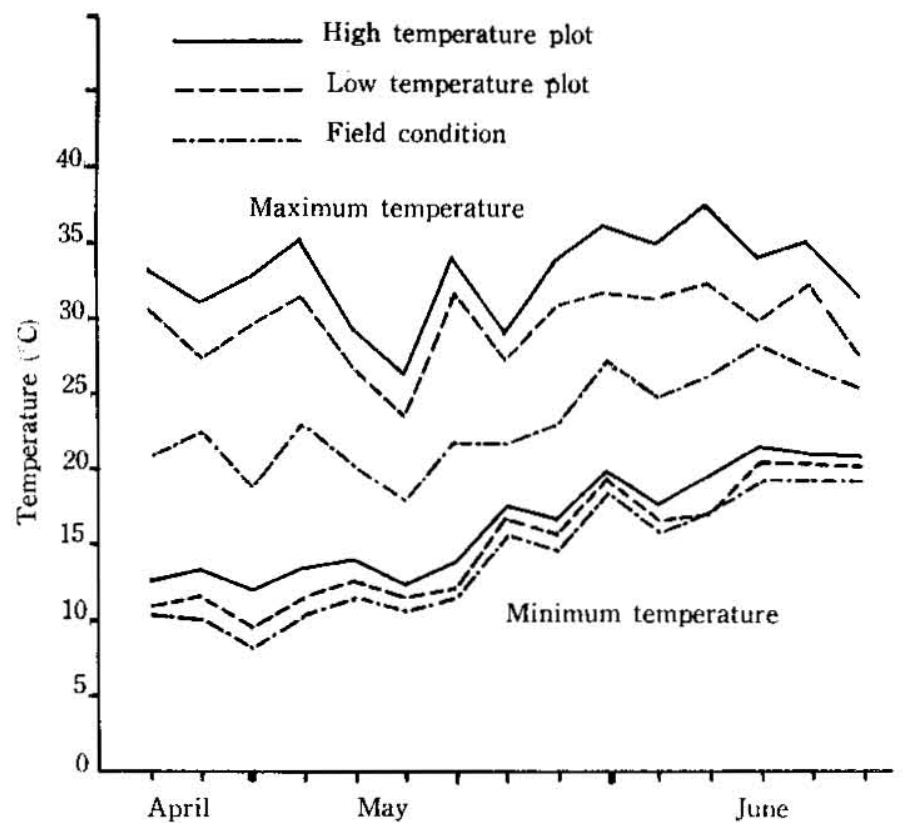

Fig. 1. Maximum and minimum temperatures in the two glasshouses.

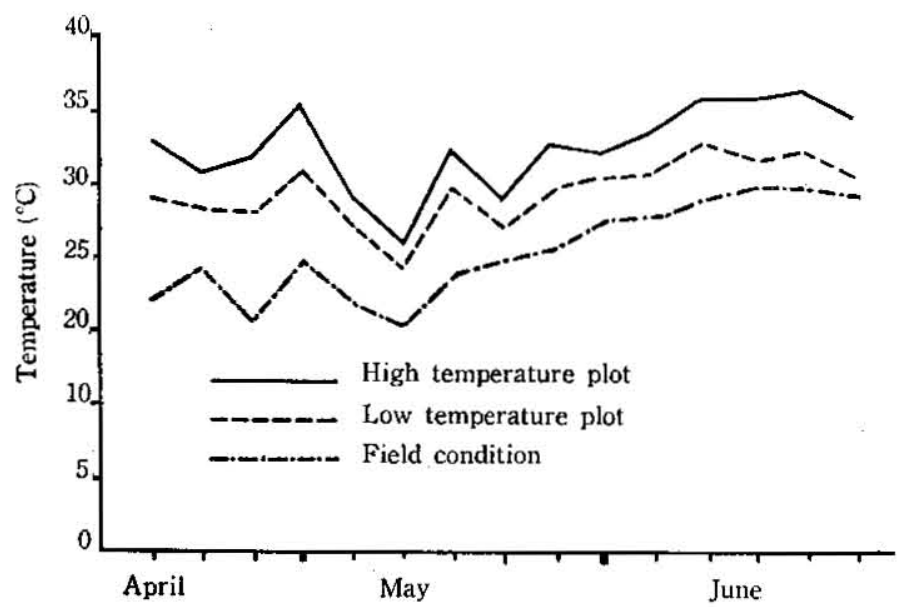

Fig. 2. Temperatures at 9 a.m. in the two glasshouses.

The soil temperatures at depth of $5 \mathrm{~cm}$. in the pot were measured at 9 a.m., 2 p.m. and 6 p.m. and Table 1 shows the results.

As shown in Table 1, soil temperatures in the high temperature plot were a little higher than those in the low temperature plot.

The relative atmospheric humidities in the two plots were measured, 
and there were not any remarkable differences between the high and low temperature plots.

Table 1. Soil temperatures in the pot at a depth of $5 \mathrm{~cm}$.

\begin{tabular}{l|r|r|r|r|r|r}
\hline \multirow{2}{*}{ Period } & \multicolumn{3}{|c||}{ High temperature plot } & \multicolumn{3}{c}{ Low temperature plot } \\
\cline { 2 - 8 } & 9 a.m. & 2 p.m. & 6 p.m. & 9 a.m. & 2 p.m. & 6 p.m. \\
\hline June 11-15 & 24.2 & 31.4 & 29.1 & 22.2 & 28.7 & 26.4 \\
June 16-20 & 25.0 & 29.1 & 28.6 & 23.6 & 27.4 & 27.3 \\
June 21-25 & 25.1 & 28.6 & 28.0 & 23.6 & 26.9 & 26.2 \\
June 26-30 & 23.5 & - & 26.9 & 22.6 & - & 25.8 \\
\hline
\end{tabular}

\section{GROWTH BEHAVIOUR AND YIELDS}

\section{a. Corn.}

Leaf emerging stage.-The plant grown in the high temperature plot was a little faster in the appearance of leaves on the main stalk than the plant grown in the low temperature one, and as shown in Figure 3 , the former was 3 days faster in the appearance of 15 th leaf

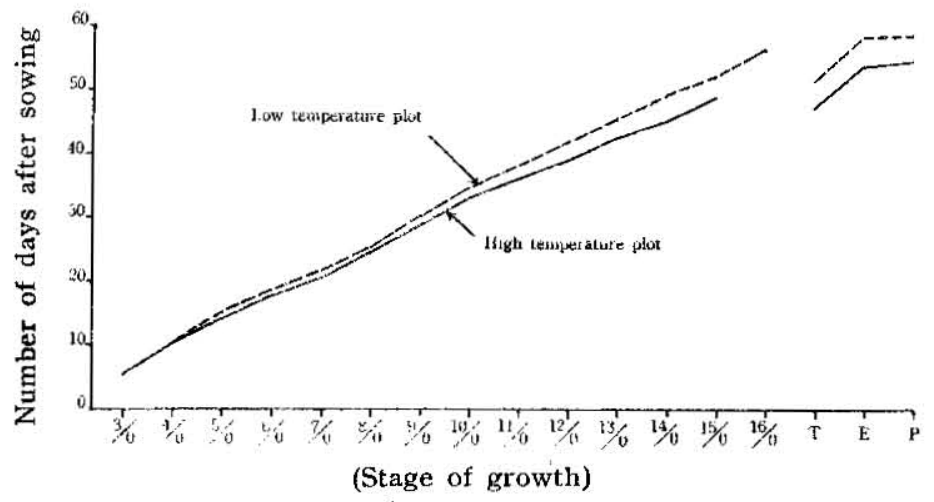

Fig. 3. Effect of temperature on the appearance of leaves on the main stalk of corn.

$\mathrm{T}=$ Beginning to tassel. $\quad \mathrm{E}=$ End of tasseling.

$\mathrm{P}=$ Beginning to shed pollen.

$(15 / 0)$ than the latter. The beginning to tassel and to shed pollen was 3 to 5 days faster in the high temperature plot than in the low temperature one.

The number of leaves on the main stalk was not always constant, but the high temperature plot was about one leaf smaller in number of leaves than the low temperature one. 
Height of plant.-Figure 4 shows that the height of plant grown in the high temperature plot was very taller than that of the low temperature one.

Length and width of blade. -As shown in Figure 5, the length of blade was longer in the high temperature plot than that of the low temperature one. On the contrary, the blade was wider in the low temperature plot than in the high temperature one.

Percentage of clinging portion of leaf.-As shown in Table 2 , the percentage of clinging portion of leaf was markedly higher in the high temperature plot than in the low temperature one at the same stage of growth.

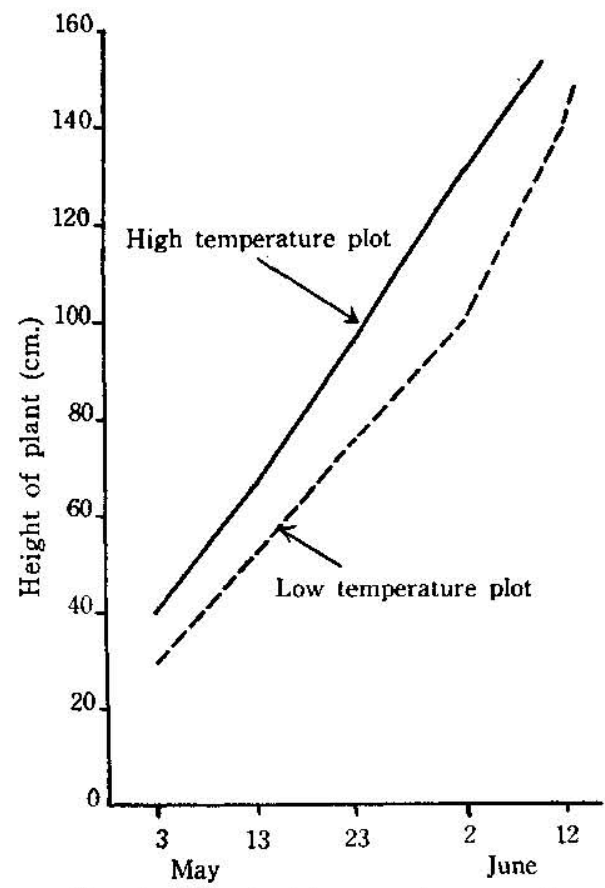

Fig. 4. Effect of temperature on the height of corn plant.

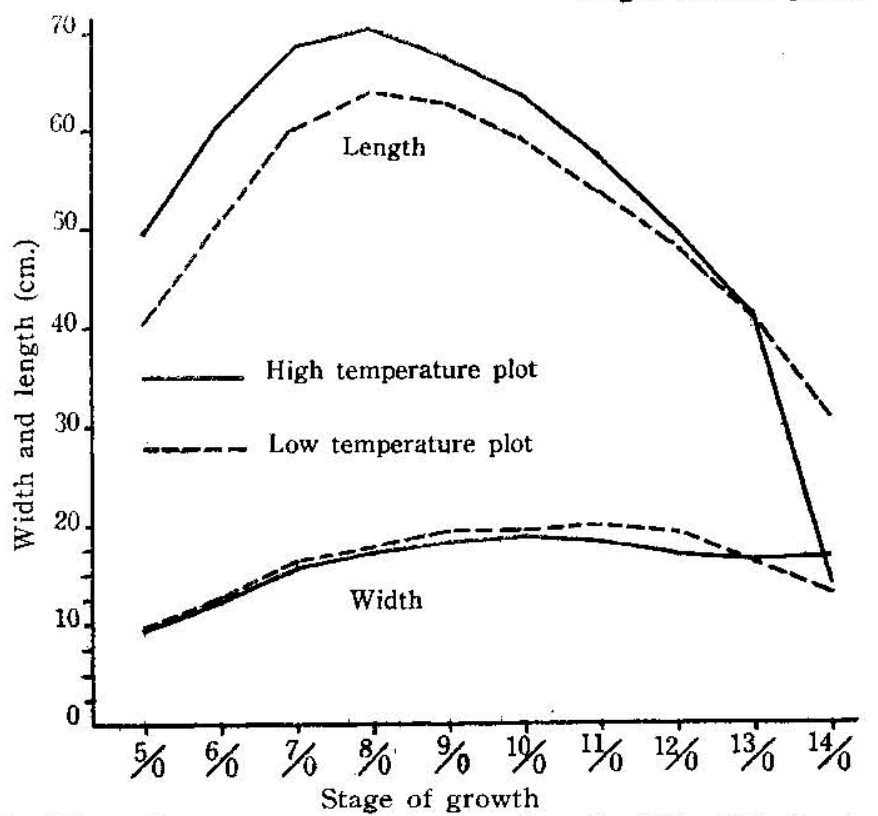

Fig. 5. Effect of temperature on the length and width of blade of corn. 
Table 2. Effect of temperature on the clinging portion of corn leaf at the harvest time.*

\begin{tabular}{l|r|r|r|r|r|r}
\hline \multirow{2}{*}{$\begin{array}{c}\text { Temperature } \\
\text { treatment }\end{array}$} & \multicolumn{7}{|c}{ Stage of growth } \\
\cline { 2 - 7 } & $2 / 0$ & $3 / 0$ & $4 / 0$ & $5 / 0$ & $6 / 0$ & $7 / 0$ \\
\hline High temperature & $100^{* *}$ & 86 & 42 & 20 & 18 & 0 \\
Low temperature & 50 & 39 & 10 & 0 & 0 & 0 \\
\hline
\end{tabular}

* Each value indicates an average of 10 plants.

** 100 presents complete clinging of leaf.

Proportion of each internode length to total internode length.Table 3 shows that the percentage of each internode length to total internode length was higher in the high temperature plot than in the low temperature plot from 4 th to 7 th internode, whereas in the internodes above 7 th internode reverse relation was shown.

Table 3. Effect of temperature on the proportion of each internode length to total internode length (at 2 days after the beginning to shed pollen, in per cent).*

\begin{tabular}{l|r|rr|r|r|rr|r|r|r|r|r|c}
\hline $\begin{array}{c}\text { Temperature } \\
\text { treatment }\end{array}$ & \multicolumn{10}{|c|}{ Order of internode } \\
\cline { 2 - 10 } & 3 & 4 & 5 & 6 & 7 & 8 & 9 & 10 & 11 & 12 & 13 & 14 & 15 \\
\hline $\begin{array}{c}\text { High } \\
\text { temperature }\end{array}$ & 0.3 & 4.0 & 6.8 & 10.1 & 11.4 & 10.1 & 10.1 & 9.3 & 9.2 & 7.0 & 5.9 & 5.8 & 9.8 \\
$\begin{array}{c}\text { Low } \\
\text { temperature }\end{array}$ & 0.3 & 2.4 & 5.3 & 8.8 & 9.9 & 11.3 & 11.5 & 9.8 & 9.7 & 8.2 & 6.7 & 6.4 & 9.6 \\
\hline
\end{tabular}

* Each value indicates an average of 10 plants.

Green and air dry weights.-The green and air dry weights of leaf, stalk, tassel and ear are given in Table 4. Data in this table are average of 5 pots, and each pot contains 2 plants. The average weights of the green and air dry leaf, stalk, tassel and ear produced in the high temperature plot were much less than those produced in the low temperature one.

Table 4. Effect of temperature on the green and air dry weights of corn plant (in grams per pot of 2 plants).

\begin{tabular}{|c|c|c|c|c|c|c|c|c|c|c|}
\hline \multirow{2}{*}{$\begin{array}{c}\text { Temperature } \\
\text { treatment }\end{array}$} & \multicolumn{5}{|c|}{ Green weight* } & \multicolumn{5}{|c|}{ Air dry weight* } \\
\hline & Leaf & Stalk & Tassel & Ear & $\begin{array}{c}\text { Whole } \\
\text { plant }\end{array}$ & Leaf & Stalk & Tassel & Ear & $\begin{array}{l}\text { Whole } \\
\text { plant }\end{array}$ \\
\hline $\begin{array}{l}\text { High } \\
\text { temperature }\end{array}$ & 191.6 & 145.1 & 19.1 & 12.4 & 368.2 & 29.2 & 14.6 & \begin{tabular}{l|l}
6 & 4.8
\end{tabular} & 1.2 & 49.8 \\
\hline $\begin{array}{l}\text { Low } \\
\text { temperature }\end{array}$ & 209.9 & 179.6 & 26.4 & 15.9 & 431.8 & 33.7 & 20.6 & 7.4 & 1.7 & 63.4 \\
\hline
\end{tabular}

* Each value indicates an average of 5 pots. 
b. Oats.

Leaf emerging stage.-As shown in Figure 6 , the plant grown in the high temperature plot was a little faster in the appearance of leaves

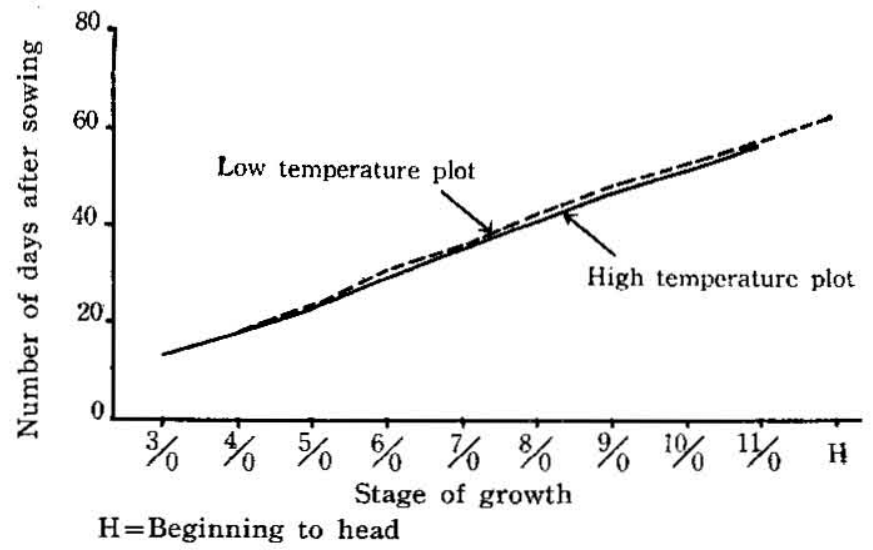

Fig. 6. Effect of temperature on the appearance of leaves on the main stalk of oats.

on the main culm than the plant grown in the low temperature one and the leaves on the main culm were about 1 smaller in number in the former than in the latter.

The heading of each culm in the high temperature plot hesitated and the heads did not completely emerge from the sheaths of top leaves and most of them stayed within the sheaths.

Height of plant.-Figure 7 shows that the height of plant grown in the high temperature plot was taller than that of the low temperature one.

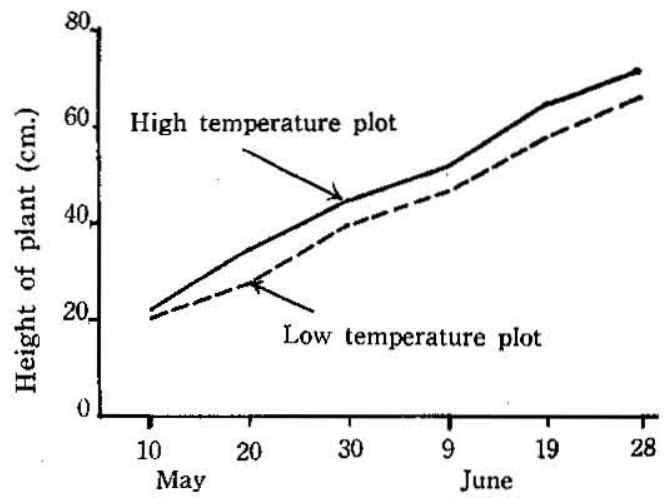

Fig. 7. Effect of temperature on the height of oats plant. 
Length and width of blade.-As shown in Table 5, the length of blade was longer in the high temperature plot than in the low temperature one. On the contrary, but blade was wider in the low temperature plot than in the high temperature plot.

Table 5. Effect of temperature on the length and width of blade on the main culm of oats (in $\mathrm{cm}$.).

\begin{tabular}{c|c|c|c|ccc}
\hline \multirow{2}{*}{$\begin{array}{c}\text { Temperature } \\
\text { treatment }\end{array}$} & \multicolumn{3}{|c||}{ Length* } & \multicolumn{3}{c}{ Width* } \\
\cline { 2 - 7 } & $6 / 0$ & $7 / 0$ & $8 / 0$ & $6 / 0$ & $7 / 0$ & $8 / 0$ \\
\hline \multirow{2}{*}{ High temperature } & 33.7 & 36.4 & 31.1 & 0.9 & 1.2 & 1.3 \\
Low temperature & 31.7 & 32.7 & 27.2 & 1.1 & 1.3 & 1.4 \\
\hline
\end{tabular}

* Each value indicates an average of 25 plants.

Percentage of clinging portion of leaf.-.-Percentage of clinging portion of leaf from each plot is given in Table 6 . The percentage of clinging portion of leaf was markedly higher in the high temperature plot than in the low temperature one at the same stage of growth.

Table 6. Effect of temperature on the clinging portion of oats leaf at the harvest time.*

\begin{tabular}{c|c|c|c|c|c}
\hline $\begin{array}{c}\text { Temperature } \\
\text { treatment }\end{array}$ & \multicolumn{7}{|c}{ Stage of growth } \\
\hline High temperature & $4 / 0$ & $5 / 0$ & $6 / 0$ & $7 / 0$ & $8 / 0$ \\
\cline { 3 - 4 } & $100^{* *}$ & 95 & 39 & 13 & 0 \\
Low temperature & 100 & 62 & 27 & 0 & 0 \\
\hline
\end{tabular}

* Each value indicates an average of 25 plants.

** 100 presents complete clinging of leaf.

Number of tillers.-Table 7 shows that the plant grown under the high temperature condition was larger in number of head-producing tillers than that grown under the low temperature one and there was the reverse relation in no head-producing tillers.

Table 7. Effect of temperature on the number of tillers of oats.

\begin{tabular}{c|c|c|c}
\hline $\begin{array}{c}\text { Temperature } \\
\text { treatment }\end{array}$ & $\begin{array}{c}\text { Total number* } \\
\text { of tillers }\end{array}$ & $\begin{array}{c}\text { Number of head ** } \\
\text { producing tillers }\end{array}$ & $\begin{array}{c}\text { Number of no * } \\
\text { head-producing } \\
\text { tillers }\end{array}$ \\
\hline High temperature & 30.6 & 12.6 & 17.8 \\
Low temperature & 29.6 & 10.4 & 19.2 \\
\hline
\end{tabular}

* Each value indicates an average of 5 pots. 
Green and air dry weights.-The green and air dry weights of main culm and tiller in grams per pot of 5 plants are given in Table 8. Data in this table are average of 5 pots. The average weight of main calm and tiller produced under the high temperature condition was greater than those produced under the low temperature condition.

Table 8. Effect of temperature on the green and air dry weights of oats (in grams per pot of 5 plants).

\begin{tabular}{c|c|c|c|c|c|c}
\hline & \multicolumn{3}{c||}{ Green weight* } & \multicolumn{3}{c}{ Air dry weight* } \\
\hline $\begin{array}{c}\text { Temperature } \\
\text { treatment }\end{array}$ & $\begin{array}{c}\text { Main } \\
\text { culm }\end{array}$ & Tiller & $\begin{array}{c}\text { Whole } \\
\text { plant }\end{array}$ & $\begin{array}{c}\text { Main } \\
\text { culm }\end{array}$ & Tiller & $\begin{array}{c}\text { Whole } \\
\text { plant }\end{array}$ \\
\hline High temperature & 42.5 & 51.1 & 93.6 & 10.5 & 9.0 & 19.5 \\
Low temperature & 42.2 & 45.1 & 87.3 & 10.1 & 8.2 & 18.3 \\
\hline
\end{tabular}

* Each value indicates an average of 5 pots.

\section{c. Red clover.}

Growth.--The growth of stem was faster at the beginning of treatment, the growth type was more erect, the flowering time was earlier and the whole plant was shorter in the high temperature plot than in the low temperature one. The petiole of plant grown under the high temperature condition remarkably elongated and the leaf of this plant was paler green color than that grown under the low temperature condition.

As shown in Table 9, the length of longest stem and the total length of branches of red clover stem grown under the low temperature condition were longer than those grown under the high temperature one at the harvest time. The branches of stem were larger in number in the former than in the latter.

Table 9. Effect of temperature on the growth of red clover.

\begin{tabular}{|c|c|c|c|c|c|}
\hline \multirow{2}{*}{$\begin{array}{l}\text { Temperature } \\
\text { treatment }\end{array}$} & \multicolumn{3}{|c|}{ Length of longest stem ${ }^{*}$} & \multirow{2}{*}{$\begin{array}{l}\text { Total number of } \\
\text { branches of stem } \\
\text { (at harvest time)* }\end{array}$} & \multirow{2}{*}{$\begin{array}{l}\text { Total length of } \\
\text { branches of stem } \\
\text { (at harvest time) }\end{array}$} \\
\hline & May 8 & May 23 & June 15 & & \\
\hline High temperature & $\begin{array}{c}\mathrm{cm} \\
4.8\end{array}$ & $\begin{array}{c}\mathrm{cm} . \\
19.6\end{array}$ & $\begin{array}{c}\mathrm{cm} . \\
61.7\end{array}$ & 25.5 & $\begin{array}{c}\mathrm{cm} . \\
529.0\end{array}$ \\
\hline Low temperature & 2.8 & 10.6 & 71.3 & 39.0 & 708.3 \\
\hline
\end{tabular}

* Each value indicates an average of 15 plants.

Green and air dry weights.-The green and air dry weights of leaf, stem and flower head in grams per pot of 3 plants are given Table 10. Data in this table are average of 5 pots. The average 
weights of the green and air dry leaf, stem and flower head produced in the high temperature plot were much less than were those in the low temperature one.

Table 10. Effect of temperature on the green and air dry weights of red clover (in grams per pot of 3 plants).

\begin{tabular}{|c|c|c|c|c|c|c|c|c|}
\hline \multirow{2}{*}{$\begin{array}{c}\text { Temperature } \\
\text { treatment }\end{array}$} & \multicolumn{4}{|c|}{ Green weight* } & \multicolumn{4}{|c|}{ Air dry weight* } \\
\hline & Leaf & Stem & $\begin{array}{l}\text { Flower } \\
\text { head }\end{array}$ & $\begin{array}{l}\text { Whole } \\
\text { plant }\end{array}$ & Leaf & Stem & $\begin{array}{l}\text { Flower } \\
\text { head }\end{array}$ & $\begin{array}{l}\text { Whole } \\
\text { plant }\end{array}$ \\
\hline $\begin{array}{l}\text { High } \\
\text { temperature }\end{array}$ & 92.3 & 66.7 & 17.3 & 176.3 & 19.1 & 15.3 & 3.5 & 37.9 \\
\hline $\begin{array}{l}\text { Low } \\
\text { temperature }\end{array}$ & 176.0 & 112.9 & 22.6 & 311.5 & 35.4 & 25.7 & 4.5 & 65.6 \\
\hline
\end{tabular}

Each value indicates an average of 5 pots.

\section{CHEMical COMPOSITION}

\section{a. Corn.}

The results of chemical analysis of corn fodder are given in Table 11.

Crude protein.-Lower leaf of corn was higher in crude protein content than upper one. This trend was more pronounced in the high temperature plot than in the low temperature one. Each leaf from the high temperature plot was markedly higher in crude protein content than that from the low temperature one. The crude protein contents of stalk and tassel were also markedly higher in the high temperature plot than in the low temperature one.

Crude fiber.- In this study, the crude fiber content of corn leaf did not show marked difference in any stage of growth in the two plots. However, the content of leaf was remarkably higher in the high temperature plot than in the low one. The stalk grown under the high temperature condition was also higher in the crude fiber content than that grown under the low temperature one, whereas the content of tassel did not show difference between the two plots.

Ether extract.-The ether extract content of corn leaf did not any difference in any stage of growth between the two plots, while the contents of stalk and tassel were higher in the high temperature plot than in the low one.

Nitrogen-free extract.-The nitrogen-free extract of corn leaf was markedly higher in the low temperature plot than in the high temperature one.

Crude ash-Temperature did not affect the crude ash content of corn leaf. The stalk and tassel from the high temperature plot were 
Table 11. Effect of temperature on the chemical composition of corn fodder. Data expressed in percentage of dry weight.

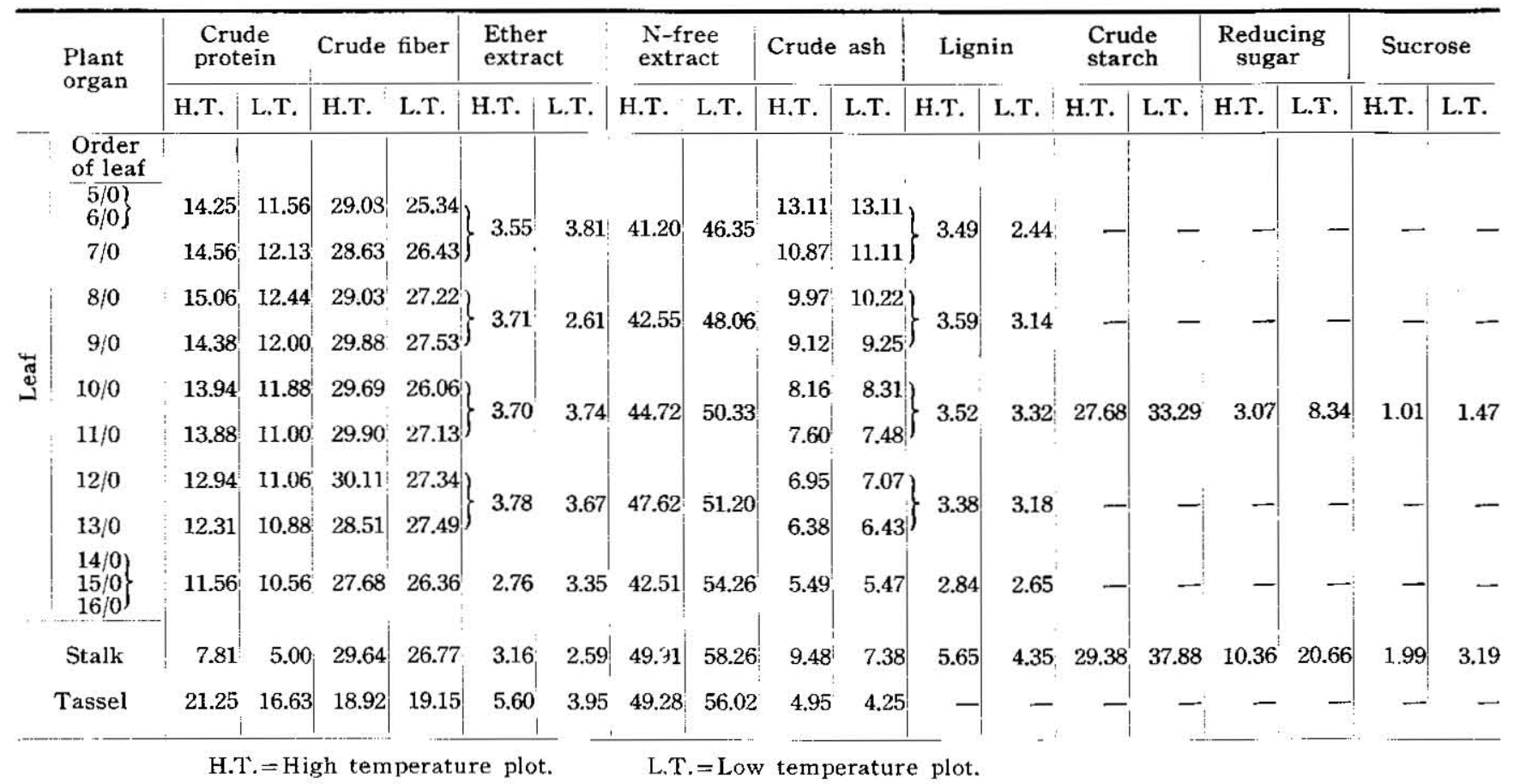


higher in the crude ash content than those from the low temperature one.

Lignin.-The lignin contents of stalk and leaf were higher in the high temperature plot than in the low temperature one.

Reducing sugar, sucrose and crude starch.--The reducing sugar (calculated as glucose) and sucrose contents of leaf and stalk were remarkably higher in the low temperature plot than in the high temperature one. The leaf and stalk of corn from the low temperature plot were higher in the crude starch content than those from the high temperature one.

b. Oats.

The results of chemical analysis of oats hay are given in Table 12 .

Crude protein.-The leaf, stem and head of main culm and all tillers of oats were higher in the crude protein content in the high temperature plot than in the low temperature one.

Crude fiber.-The leaf and stem of main culm and tiller did not show difference in the crude fiber content between the two plots, while the content of head was lower in the low temperature plot than in the high temperature one.

Ether extract.-The ether extract contents of leaf and head of main culm and all tillers from the high temperature plot were a little higher than those from the low temperature one.

Nitrogen-free extract.-The all organs of oats produced in the low temperature plot were higher in the nitrogen-free extract content than those produced in the high temperature one.

Crude ash.-The all organs of oats grown under the high temperature condition were higher in the crude ash content than those grown under the low temperature one.

Lignin.-The lignin content of stem of main culm produced in the high temperature plot was a little higher than that produced in the low temperature plot.

Reducing sugar, sucrose and crude starch.- The leaf and stem of main culm grown under the low temperatnre condition were higher in the crude starch, reducing sugar and sucrose than those grown under the high temperature condition.

\section{c. Red clover.}

The results of chemical analysis of red clover hay are given in Table 13.

Crude protein.-The crude protein content of red clover leaf was higher in the high temperature plot than in the low temperature one, the stem did not show difference in the crude protein content between the two plots. 
Table 12. Effect of temperature on the chemical composition of oats hay.

Data expressed in percentage of dry weight.

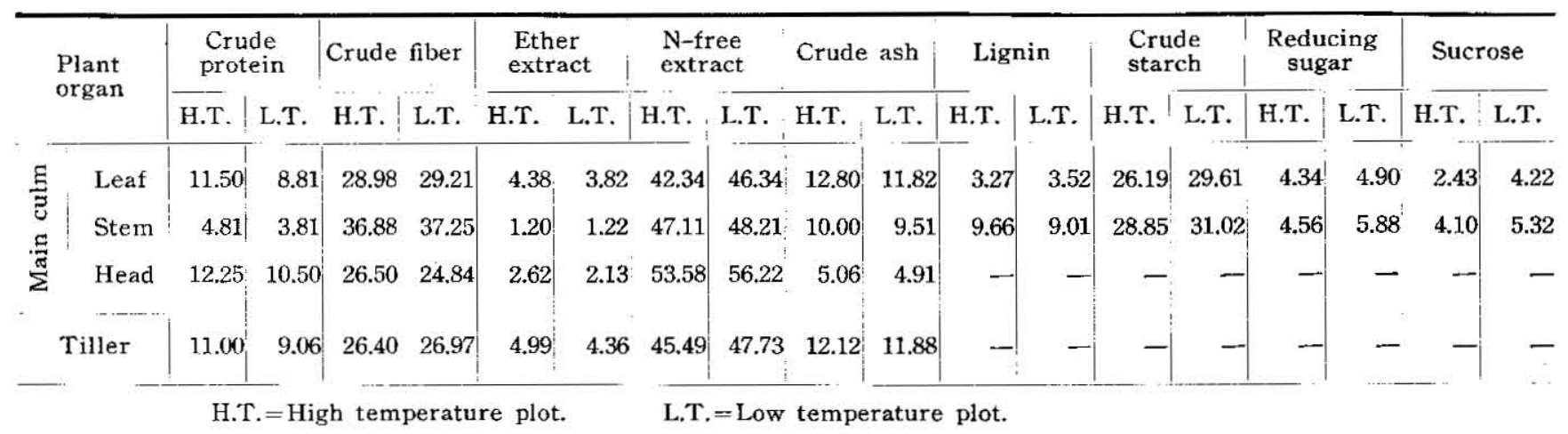

Table 13. Effect of temperature on the chemical composition of red clover hay.

Data expressed in percentage of dry weight.

\begin{tabular}{|c|c|c|c|c|c|c|c|c|c|c|c|c|c|c|c|c|c|c|}
\hline \multirow{2}{*}{$\begin{array}{l}\text { Plant } \\
\text { organ }\end{array}$} & \multicolumn{2}{|c|}{$\begin{array}{l}\text { Crude } \\
\text { protein }\end{array}$} & \multicolumn{2}{|c|}{ Crude fiber } & \multicolumn{2}{|c|}{$\begin{array}{l}\text { Ether } \\
\text { extract }\end{array}$} & \multicolumn{2}{|c|}{$\begin{array}{l}\text { N-free } \\
\text { extract }\end{array}$} & \multicolumn{2}{|c|}{ Crude ash } & \multicolumn{2}{|c|}{ Lignin } & \multicolumn{2}{|c|}{$\begin{array}{l}\text { Crude } \\
\text { starch }\end{array}$} & \multicolumn{2}{|c|}{$\begin{array}{l}\text { Reducing } \\
\text { sugar }\end{array}$} & \multicolumn{2}{|c|}{ Sucrose } \\
\hline & H.T. & L.T. & H.T. & L.T. & H.T. & L.T. & H.T. & L.T. & H.T. & L.T. & H.T. & L.T. & H.T. & L.T. & H.T. & L.T. & H.T. & L.T. \\
\hline Leaf & 17.22 & 15.83 & 18.85 & 18.48 & 5.85 & 5.97 & 46.62 & 48.92 & 11.47 & 10.80 & 2.24 & 2.22 & 19.35 & 19.79 & 2.26 & 3.78 & 0.25 & 0.37 \\
\hline Stem & $\begin{array}{r}6.02 \\
\end{array}$ & 6.31 & 31.82 & 31.23 & 2.57 & 2.51 & 52.25 & 53.85 & 7.34 & 6.11 & 5.97 & 5.13 & 33.85 & 34.65 & 7.35 & 8.93 & 1.43 & 2.61 \\
\hline
\end{tabular}


Crude fiber.-The temperature did not affect the crude fiber contents of red clover leaf and stem.

Ether extract.-There is no difference in the ether extract content of red clover between the high and low temperature plots.

Nitrogen-free extract. - The nitrogen-free extract contents of leaf and stem were somewhat higher in the low temperature plot than in the high temperature one.

Crude ash:--The leaf and stem of red clover grown under the high temperature condition were higher in the crude ash content than those grown under the low temperature one.

Lignin.-The lignin content of red clover leaf did not show any difference between the high and low temperature plots, while the content of. stem was higher in the high temperature plot than in the low temperature one.

Reducing sugar, sucrose and crude starch:-The reducing sugar, sucrose and crude starch contents of leaf and stem of red clover grown under the low temperature condition were higher than those grown under the high temperature condition.

\section{DISCUSSION}

This experiment was conducted under the glasshouse conditions during relatively warm season, therefore it is necessary to consider that the temperatures of this experiment were extraordinarily higher than those of natural conditions in Kyushu. The results of this experiment must be discussed under this consideration.

In general, it seems that the high temperature fastened the pace of growth of the three crops. For corn and oats, the high temperature in this experiment appeared to be more favorable for the growth of plant height than did the Iow temperature, while this temperature response was reverse in red clover. The result of experiment with corn agrees with the author's previous report.

The high temperature promoted the elongation of lower internodes and the low temperature promoted the elongation of higher internodes of corn. The elongation of lower internodes probably partly accounts for the lodging of corn plant.

The low temperature was more favorable for the maintenance of greeness of corn and oats leaves than did the high temperature, and the maintenance of leaf greeness perhaps is important for forage crops.

It seems that the extraordinarily high temperature interfered with smooth emergence of oats head, and the blade length of corn and oats was longer in the high temperature plot than in the low temperature one and the blade width of the two crops was larger in the latter than 
in the former. Red clover showed the small type of growth under the high temperature condition. These fact indicates the extraordinarily high temperature was probably unfavorable for normal growth of the three crops.

Under the conditions of this experiment, for corn and red clover the low temperature appeared to be more favorable for the production of fresh and air dry herbages than did the high temperature, whereas in oats the reverse relation was observed.

The crude protein contents of corn, oats and red clover grown under the high temperature condition were higher than those grown under the low temperature one. According to Brown (1937), the percentage of crude protein declined slightly in Kentucky and Canada bluegrass and orchard grass as the temperature increased from $40^{\circ}$ to $60^{\circ} \mathrm{F}$. and then increased slightly as the temperature rose above the optimum for growth. The author's result was obtained under extraordinarily higher temperature than Brown's experiment, therefore it seems that the extraordinarily high temperature increased the protein contents of corn, oats and red clover. This result agrees with that the result of Brown's experiment which was carried out under the higher temperature condition and that of the experiment with red clover by Delwiche and Tottingham (1930).

However, the crude fiber content of leaf and stalk of corn grown under the high temperature condition was a little higher than that of the low temperature one, and the lignin contents of corn and red clover were higher under the former than under the latter.

The unfavorable effect of the high temperature on the crude fiber and lignin contents of corn, oats and red clover canceled the favorable effect of the high temperature on the crude protein contents of these three crops as forage crops.

The crude starch, reducing sugar and sucrose contents of corn, oats and red clover grown under the low temperature condition were much higher than those of the high temperature one, and those results agree with those of Brown's experiment with Kentucky and Canada bluegrass, orchard grass and Bermuda grass and those of the experiments with the other crops by the other investigators.

The following observation seems justified under the conditions of the experiment.

The extraordinarily high temperature increased the protein content and the proportion of skeletal material in corn, oats and red clover, and the low temperature increased the carbohydrate content. It seems reasonable to conclude that the extraordinarily high temperature is an unfavorable factor for the palatability of fodder corn, oats and red clover hay as the sugar content accounts for the palatability of forage 
crops, and the responsibility of growth and chemical composition to temperature depends on the species of forage crops.

\section{SUMMARY}

1. A partial review of literature dealing with the effect of temperature on the growth and chemical composition of forage and the other crops is presented.

2. Corn, oats and red clover were grown in glasshouses and the effect of different temperature treatments on their growth and chemical composition was determined. The temperatures used in this experiment were extraordinarily higher than those in the field conditions.

3. A high temperature fastened the appearance of leaf on the main stalk of corn and leaf on the main culm of oats, tasseling of corn and heading of oats.

The height of corn and oats was taller in the high temperature plot than in the low temperature one. The flowering time of red clover was fastened in the high temperature plot, while the growth type was shorter in the high temperature plot than in the low temperature one.

4. The percentage of each internode length to total internode length of corn was higher in the high temperature plot than in the low temperature one from 4 th to 7 th internode, whereas in the internodes above 7 th internode reverse relation was shown.

5. The percentage of clinging portion of corn and oats leaf grown under the high temperature condition was larger than that grown under the low temperature one.

6. It seems that the extraordinarily high temperature interfered with smooth emergence of oats head. The blade length of corn and oats was larger in the high temperature plot than in the low temperature one, while the blade width was larger in the latter than in the former.

7. In this experiment, average green and air dry weights of each organ of corn and red clover produced in the high temperature plot were much less than those produced in the low temperature one, whereas there was the reverse relation in oats.

8. Lower leaf of corn was higher in the crude protein content than upper one. This trend was more pronounced in the high temperature plot than in the low temperature one. Each organ of three crops grown under the high temperature condition was higher in the crude protein content than those grown under the low temperature one with the exception of red clover stem.

9. The crude fiber content of leaf and stalk of corn and head of oats 
grown under the high temperature condition was higher than those grown under the low temperature one.

10. Each organ of oats and red clover did not show difference in the crude fiber content between the two plots.

11. The ether extract content of corn stalk and tassel and all organs of oats was higher in the high temperature plot than in the low one.

12. The nitrogen-free extract content of corn leaf, all organs of oats and red clover was higher in the low temperature plot than in the high temperature one.

13. The stalk and tassel of corn and all organs of oats and red clover grown under the high temperature condition were higher in the crude ash content than those grown under the low temperature one.

14. The lignin content of corn stalk and leaf and red clover stem was higher in the high temperature plot than in the low one.

15. The leaf and stalk of corn, leaf and main culm of oats and red clover leaf and stem grown under the low temperature condition were higher in the reducing sugar, sucrose and crude starch than those grown under the high temperature condition.

\section{LITERATURE CITED}

1. Brown, E. M. 1939. Some effects of temperature on the growth and chemical composition of certain pasture grasses. Missouri Agr. Expt. Sta. Research Bul., 299.

2. Delwiche, E. J. and Tottingham, W. E. 1930. Effect of climate on nitrogen content of maize, barley, and red clover. Jour. Amer. Soc. Agron., 30 : 681-688.

3. Ehara, K., Matsumoto, S. and Sawada, T. 1956. Studies on the growth behaviour and quality of the forage crops in warm area in Japan. I. Effect of growing season on the growth, structure, and chemical composition of the internodes of corn fodder at various growing stages. Kyushu Agr. Expt. Sta. Bul., 4 : 175-195.

4. Fujita, T. 1941-41. Physiologische Untersuchungen über die Veränderung der Membranstoffe an den höheren Pflanzen mit besonderer Berücksichtigung der Verholzung. V. Einfluss der Lufttemperatur auf den Membranstoffgehalt und den Verhärtungsgrad der Pflanzen. Bul. Sci. Kjuŝu Imperia Universitato, Fukuoka, Japanujo, 9:512-523. (in Japanese).

5. Gist, G. R. and Mott, G. O. 1957. Some effects of light intensity, temperature, and soil moisture on the growth of alfalfa, red clover and birdsfoot trefoil seedlings. Agron. Jour., 49: 33-36.

6. Hurd Karrer, A. M. and Dickson, A. D. 1934. Carbohydrate and nitrogen relations in wheat plants with reference to type of growth under different environmental conditions. Plant Physiol., 9: 533-565.

7. Lundegardh, H. 1954. Klima und Boden in ihrer Wirkung auf das Pflanzenleben. 92-152. 
8. Meyer, B. S. 1928. Seasonal variation in the physical and chemical properties of the leaves of the pitch pine, with special reference to cold resistance. Amer. Jour. Bot., 15: 449-472.

9. Newton, R. 1922. A comparative study of winter wheat varieties with special reference to winter killing. Jour. Agr. Sci., 12: 1-19.

10. - 1924. Colloidal properties of winter wheat plants in relation to frost resistance. Jour. Agr. Sci., 14: 178-191.

11. Nightingale, G. T. 1934. Effects of temperature on metabolism in tomato. Bot. Gaz., 95: 35-58.

12. - 1935. Effects of temperature on growth, anatomy, and metabolism of apple and peach roots. Bot. Gaz., $96: 581-639$.

13. Senju, R., Nakamura, K. and Ehara, K. 1955. Determination of lignin in herbage plant by colloid-titration. Kyushu Sakumotsu Danwakai, 9: 51-56. (in Japanese).

14. Sullivan, J. T. and Sprague, V. G. 1949. The effect of temperature on the growth and composition of the stubble and roots of perennial ryegrass. Plant Physiol., 24: 706-719.

15. Tottingham, W. E. 1923. Temperature effects in plant metabolism. Jour. Agr. Res., 25: 13-30.

16. Ulrich, A. 1955. Influence of night temperature and nitrogen nutrition on the growth, sucrose accumulation and leaf minerals of sugar beet plants. Plant Physiol., 30 : 250-257.

17. Vassiliev, I. M. and Vassiliev, M. G. 1936. Changes in carbohydrate content of wheat plants during the process of hardening for drought resistance. Plant Physiol., 11 : 115-125.

18. Vinall, H. N. and Hein, M A. 1937. Breeding miscellaneous grasses. Year book of Agriculture 1937, 1032-1102.

19. Walster, H. L. 1920. Formative effects of high and low temperatures upon growth of barley: a chemical correlation. Bot. Gaz., 69: 97-126.

20. Weinmann, H. 1948. Underground development and reserves of grasses. Jour. Brit. Grassl. Soc., $3: 115-140$. 